\title{
A TISZTESSÉGTELEN KERESKEDELMI GYAKORLATOK SZABÁlYOZÁSA ÉS JOGGYAKORLATA MAGYARORSZÁGON ${ }^{\mathrm{I}}$
}

\author{
ZAVODNYIK JóZSEF
}

Debreceni Jogi Mühely, 2020. ÉVi (XVII. évfolyam) I-2. DOI $10.24169 / \mathrm{DJM} / 2020 / \mathrm{I}-2 / 7$

A fogyasztókkal szemben tanúsított tisztességtelen kereskedelmi gyakorlatokkal szembeni fellépésnek több formája áll a fogyasztók, a versenytársak és a hatóságok rendelkezésére. Magyarországon a fogyasztók érdekeit védelmező, - csekély állami támogatásban részesülő - egyesületek erőtlensége következtében a tisztességtelen kereskedelmi gyakorlatokkal szembeni fellépés elsősorban hatósági feladatként jelentkezik. Az alábbiakban a hatósági fellépés egyes kérdéseit tekintjük át, de továbbá ismertetjük azt is, hogy a fogyasztók és a fogyasztói érdekképviseleti szervek miként fordulhatnak a hatóságokhoz és a bírósághoz.

A fenti témákat érintő áttekintés során a jelenlegi jogszabályi rendelkezéseket összevetjük az uniós fogyasztóvédelmi szabályok hatékonyabb végrehajtása és korszerűsítése érdekében a 93/13/EGK irányelv, a 98/6/EK európai parlamenti és tanácsi irányelv, a 2005/29/EK európai parlamenti és tanácsi irányelv, valamint a 2011/83/EU európai parlamenti és tanácsi irányelv módosításáról szóló irányelvben ${ }^{2}$ foglaltakkal, megvizsgálva, hogy szükségesnek mutatkozik-e a magyar szabályozás változtatása az uniós előírások nyomán.

\section{A hatóságok fellépése a tisztességtelen kereskedelmi gyakorlatokkal szemben}

A fogyasztókkal szembeni tisztességtelen kereskedelmi gyakorlatok tilalmának Magyarországon három hatóság szerez érvényt, amelyeket a belső piacon az üzleti vállalkozások fogyasztókkal szemben folytatott tisztességtelen kereskedelmi gyakorlatairól, valamint a 84/450/EGK tanácsi irányelv,

1 A tanulmány megírása és megjelentetése az Igazságügyi Minisztérium jogászképzés színvonalának emelését célzó programjai keretében valósult meg.

2 Az Európai Parlament és a Tanács 2019/2161 irányelve (2019. november 27.) a 93/13/EGK tanácsi irányelvnek, valamint a 98/6/EK, a 2005/29/EK és a 2011/83/EU európai parlamenti és tanácsi irányelvnek az uniós fogyasztóvédelmi szabályok hatékonyabb végrehajtása és korszerüsítése tekintetében történő módosításáról, HL L 328., 2019.12.18., 7-28. 
a 97/7/EK, a 98/27/EK és a 2002/65/EK európai parlamenti és tanácsi irányelvek, valamint a 2006/2004/EK európai parlamenti és tanácsi rendelet módosításáról szóló európai parlamenti és tanácsi 2005/29/EK irányelvet ${ }^{3}$ (továbbiakban: 2005/29/EK irányelv) átültető magyar jogszabály, a fogyasztókkal szembeni tisztességtelen kereskedelmi gyakorlat tilalmáról szóló 2008. évi XLVII. törvény (továbbiakban: Fttv.) határoz meg:

- főszabály szerint a fogyasztóvédelmi hatóság jogosult eljárni, ${ }^{4}$

- pénzügyi szervezet esetén a Magyar Nemzeti Bank („MNB”) folytatja le az eljárást,

- ha a kereskedelmi gyakorlat a gazdasági verseny érdemi befolyásolására alkalmas, akkora Gazdasági Versenyhivatal („GVH”) járel.A gazdasági verseny érdemi érintettségének megállapításánál figyelembe veendő az alkalmazott kereskedelmi gyakorlat kiterjedtsége (a kommunikáció eszközének jellege, a jogsértéssel érintett földrajzi terület nagysága, a jogsértéssel érintett üzletek száma, a jogsértés időtartama vagy a jogsértéssel érintett áru mennyisége) vagy a jogsértésért felelős vállalkozás mérete a nettó árbevétel nagysága. Egyes esetekben a gazdasági verseny érdemi érintettsége minden egyéb körülményre tekintet nélkül fennáll, így például, ha a reklám országos televíziós csatornán jelent meg vagy országos terjesztésű újságban. ${ }^{5}$

A tisztességtelen kereskedelmi gyakorlatok ügyében hatáskörrel rendelkező hatóságok nemcsak magyarországi székhelyü vállalkozásokkal szemben járhatnak el, évente néhány alkalommal más tagállamban székhellyel rendelkező vállalkozásokkal szemben is eljárnak. Az ilyen eljárások eddigi tapasztalatai kedvezőtlenek, az eljárás lefolytatása nehézségekbe ütközött. ${ }^{6} \mathrm{~A}$ fogyasztóvédelmi

3 Az Európai Parlament és a Tanács 2005/29/EK irányelve (2005. május 11.) a belső piacon az üzleti vállalkozások fogyasztókkal szemben folytatott tisztességtelen kereskedelmi gyakorlatairól, valamint a 84/450/EGK tanácsi irányelv, a 97/7/EK, a 98/27/EK és a 2002/65/EK európai parlamenti és tanácsi irányelvek, valamint a 2006/2004/EK európai parlamenti és tanácsi rendelet módosításáról, HL L 149, 2005.6.11. 22-39.

4 A magyar fogyasztóvédelmi intézményrendszerről, annak átalakulásairól lásd pl. Lévayné F. J. - Lévay M.: A fogyasztóvédelem alkotmányossági kérdéseiről és a magyar fogyasztóvédelmi intézményrendszer változásairól. In: Homicskó Á. O. - Szuchy R. (szerk.): Studia in honorem Péter Miskolczi-Bodnár. Károli Gáspár Református Egyetem Állam- és Jogtudományi Kar, Budapest, 2017. 379-387.

5 Fttv. 10-11. $\$$

6 Megjegyzendő, hogy a nehézségek nem a nagy vállalkozások esetén jelentkeztek [lásd pl. Facebook Ireland Ltd. (Vj/85/2016.), Google LLC (Vj/88/2016.), Airbnb Ireland (Vj/89/2016.)], hanem a kifejezetten a fogyasztók megtévesztésére alapított kereskedelmi gyakorlatokat tanúsító kisebb vállalkozásokkal szembeni eljárásokban (lásd pl. a Vj/122/2010. számú ügyet). 


\section{TisZTeSSÉGTELEN KERESKEDELMi GYAKORLATOK - MagYARORSZÁG}

jogszabályok végrehajtásáért felelős nemzeti hatóságok közötti együttműködésről és a 2006/2004/EK rendelet hatályon kívül helyezéséről szóló 2017/2394/EU rendelet $^{7}$ (továbbiakban: 2017/2394/EU rendelet) remélhetően hatékonyabbá teszi majd ezeket az eljárásokat.

\section{Az átlagfogyasztó megítélése a hatóságok gyakorlatában}

A magyar szabályozásban, az Fttv.-ben nem jelenik meg az „átlagfogyasztó” fogalma. Az Fttv. értelmében a kereskedelmi gyakorlat megítélése, az ügyleti döntés befolyásolásának vizsgálata során az olyan fogyasztó magatartását kell alapul venni, aki észszerűen tájékozottan, az adott helyzetben általában elvárható figyelmességgel és körültekintéssel jár el, figyelembe véve az adott kereskedelmi gyakorlat, illetve áru nyelvi, kulturális és szociális vonatkozásait is. ${ }^{8}$

A vállalkozások által tanúsított kereskedelmi gyakorlat, annak a fogyasztói magatartásokra, ügyleti döntésekre gyakorlat hatása, az erre való alkalmassága az átlagfogyasztó mint mérce, viszonyítási alap szemszögéből kerül megítélésre.

A fogyasztókkal szembeni tisztességtelen kereskedelmi gyakorlat tilalmával kapcsolatban eljáró hatóságok döntései és így jogértelmezései kizárólag a GVH esetében ismerhetők meg teljesen, a fogyasztóvédelmi hatóság és az MNB nem hozza nyilvánosságra döntéseinek indokolását. Kizárólag a GVH, illetőleg a hatósági döntések felülvizsgálatát végző bíróságok joggyakorlatára tudunk támaszkodni annak vizsgálata során, hogy a hatóságok milyen átlagfogyasztót tartanak szem előtt eljárásaik során.

$\mathrm{Az}$ átlagfogyasztó a magyar joggyakorlat szerint is az átlagos, észszerủen jól informált, körültekintő és figyelmes fogyasztó. Ő az utca embere, a nagy többséghez hasonló mindennapi ember. Az ilyen átlagos fogyasztó az adott helyzetben általában elvárható figyelmességgel és körültekintéssel jár el, azaz nem

7 Az Európai Parlament és a Tanács (EU) 2017/2394 rendelete (2017. december 12.) a fogyasztóvédelmi jogszabályok végrehajtásáért felelős nemzeti hatóságok közötti együttműködésről és a 2006/2004/EK rendelet hatályon kívül helyezéséről, HL L 345., 2017.12.27., 1-26.

8 Fttv. 4. $\$$ (1) bekezdés. Az átlagfogyasztó uniós és magyar fogalmáról lásd Balogh V.: Az átlagfogyasztó fogalmával kapcsolatos egyes kérdések. In: Fazekas M. (szerk.): Jogi Tanulmányok. Jogtudományi elöadások az Eötvös Loránd Tudományegyetem Állam-és Jogtudományi Kar Doktori Iskoláinak konferenciáján. ELTE Állam- és Jogtudományi Kar Állam- és Jogtudományi Doktori Iskola, Budapest, 2016. Lásd továbbá Zavodnyik J.: Nagykommentár a tisztességtelen kereskedelmi gyakorlatról szóló törvényhez. Wolters Kluwer, Budapest, 2013. 110-123.

9 Az uniós jogalkotásban és az Európai Unió Bíróságának joggyakorlatában megjelenő fogyasztói képről lásd Papp M.: Kivel szemben tisztességtelen? Gondolatok az európai uniós fogyasztói képről és az Európai Unió Bírósága által biztosított jogvédelem szintjéről. Versenytükör, 2016/1., 28-37. 
szélsőséges személyek, így nem rendkívüli képességekkel rendelkező, kiemelkedő tudású emberek, de nem is a beszámítási képességgel kevéssé vagy egyáltalán nem rendelkező gyengeelméjü. ${ }^{10} \mathrm{Az}$ átlagfogyasztó nem gyanakszik, bízik az üzleti tisztesség követelményének érvényesülésében, abban, hogy a számára adott tájékoztatás igaz, pontos. Az átlagfogyasztó a saját tapasztalatait figyelembe veszi a reklámállítások értelmezésekor, ez azonban nem jelenti azt, hogy a reklámozó bármit állíthat, hiszen a fogyasztó a saját tapasztalata alapján úgyis tudja, hogy az nem igaz. Az átlagfogyasztó nem köteles utánajárni a reklámállítások valóságának, nem kell ellenőriznie azokat, sőt kételkednie sem kell bennük. ${ }^{11} \mathrm{Az}$ átlagfogyasztó bizalommal fordul a reklámok felé. ${ }^{12}$

$\mathrm{Az}$ átlagfogyasztó tulajdonságainak, viselkedésének megállapítása során a hatóság nincs kötve a vállalkozások által szolgáltatott vagy más forrásokból származó piaci adatokhoz, piackutatásokhoz, azonban ezeket figyelembe veheti. A magyar hatóságok és bíróságok - a 2005/29/EK irányelv (18) preambulumbekezdését szem előtt tartva - abból indulnak ki, hogy az átlagfogyasztókra vonatkozó vizsgálat nem statisztikai alapú vizsgálat, s az eljáró bíróságok és hatóságok saját mérlegelési jogkörükben határozzák meg az átlagfogyasztó adott esetben tanúsított jellegzetes viselkedését. Az átlagfogyasztó, illetőleg a kereskedelmi gyakorlat által megcélzott (adott esetben sérülékeny) fogyasztói csoport tulajdonságainak meghatározása során a hatóságok és a bíróságok mérlegelési jogukkal élnek, mindazonáltal arra is lehetőségük van, hogy közvélemény-kutatást vagy szakértőt vegyenek igénybe az átlagfogyasztó magatartásának megállapításához. Ezzel jellemzően nem élnek. A hatósági döntéssel szembeni bírósági eljárás során a vállalkozásoknak lehetőségük vannak annak bizonyítására, hogy a hatóság tévesen állapította meg az átlagfogyasztó tulajdonságait, a kereskedelmi gyakorlatnak a fogyasztók ügyleti döntéseire gyakorolt hatását.

10 Fővárosi Ítélőtábla 2.Kf.27.171/2012/4. (Vj/3/2010.)

11 Vö. pl. a Vj/17/2015. számú ügyben hozott döntéssel.

12 Lásd pl. a Kúria Kfv.II.37.124/2013/8. számú, a Fővárosi Ítélőtábla 2.Kf.27.024/2012/10. számú ítéletét hatályában fenntartó ítéletét $(\mathrm{Vj} / 145 / 2007$.$) .$ 


\section{A jogkövetkezmények alkalmazása a jogsértő vállalkozásokkal szemben}

\subsection{A jogkövetkezmények alkalmazásának általános szabályai}

Ha a fogyasztóvédelmi hatóság vagy az MNB eljárása során megállapítja, hogy a vállalkozás tisztességtelen kereskedelmi gyakorlatot tanúsított, egyebek között a következő jogkövetkezményeket állapíthatja meg: elrendelheti a jogsértő állapot megszüntetését, megtilthatja a jogsértő magatartás folytatását, határidő tűzésével a feltárt hibák, hiányosságok megszüntetésére kötelezheti a vállalkozást, felhívhat a szükséges intézkedések és a jogszabályok betartására, a jogszerü állapot helyreállításáig feltételhez kötheti vagy megtilthatja az áru forgalmazását, illetve értékesítését, továbbá fogyasztóvédelmi bírságot szabhat ki. ${ }^{13}$

Ha bírság kiszabására kerül sor, annak összegét a fogyasztóvédelmi hatóság a jogsértés súlyának, a jogsértő állapot időtartamának, a jogsértő magatartás ismételt tanúsításának, illetve a jogsértéssel elért előny figyelembevételével állapítja meg. A szempontok ennél részletesebben sem jogszabályban, sem más módon nem kerülnek meghatározásra, így a szempontok előzetesen nem ismerhetők meg a vállalkozások számára.

Az MNB a bírság összegének megállapításakor a következő szempontokat veszi figyelembe: a jogsértés súlyossága, a jogsértés ügyfelekre gyakorolt hatása, a jogsértéssel előidézett kockázat, a kár mértéke, illetve a sérelemdíj-követelés alapjául szolgáló személyiségi jogsérelem nagysága és a kárenyhítési hajlandóság, a felelős személyek által az MNB-vel kapcsolatban tanúsított együttműködésre, a vállalkozás jó- vagy rosszhiszeműségére, a vállalkozás általa a szabályszegéssel vagy a mulasztással elért vagyoni előny és az elkerült vagyoni hátránya, az intézkedés alapjául szolgáló adatok, tények, információk eltitkolása, illetve annak szándéka, a szabályok megsértésének ismétlődése és gyakorisága. ${ }^{14}$

Mivel ezek a szempontok jogszabályba foglaltak, a vállalkozások számára előzetesen megismerhetők. Az ugyanakkor sem a fogyasztók, sem a vállalkozások számára nem előzetesen nem megismerhető, hogy a fogyasztóvédelmi hatóság és az MNB miként veszi figyelembe a jogszabályokban meghatározott szempontokat.

13 A fogyasztóvédelemről szóló 1997. évi CLV. törvény (továbbiakban: Fgytv.) 47. \$ (1) bekezdés, a Magyar Nemzeti Bankról szóló 2013. évi CXXXIX. törvény (továbbiakban: MNBtv.) 88. \$ (1) bekezdés.

14 MNBtv. 75. $\$(4)$ bekezdés a), c) és e)-i) pontok, 88. $\$$ (1) bekezdés. 
Ha a GVH jár el az Fttv. megsértése miatt, akkor a következő döntéseket hozhatja: megállapítja a jogsértés tényét, elrendeli a jogsértő állapot megszüntetését, megtiltja a jogsértő magatartás további folytatását, jogsértés megállapítása esetén kötelezettséget ír elő, elrendeli a jogsértő tájékoztatással kapcsolatban helyreigazító nyilatkozat közzétételét, bírságot szab ki, figyelmeztetést alkalmaz arra vonatkozó kötelezettség előírása mellett, hogy a vállalkozás alakítson ki a versenyjogi előírásoknak való megfelelést és a jogsértés megelőzését biztosító belső eljárásrendet, a vállalkozást a kötelezettségvállalás teljesítésére kötelezi, továbbá megállapíthatja, hogy a magatartás nem jogsértő. ${ }^{15}$

Ha a GVH bírságot szab ki, akkor a bírság összegét az eset összes körülményeire, így különösen a jogsérelem súlyára, a jogsértő állapot időtartamára, a jogsértéssel elért előnyre, a jogsértő piaci helyzetére, a magatartás felróhatóságára, az eljárást segítő együttműködő magatartására, a jogsértő magatartás ismételt tanúsítására, gyakoriságára tekintettel határozza meg. A jogsérelem súlyát különösen a gazdasági verseny veszélyeztetettségének foka, a végső üzletfelek érdekei sérelmének köre, kiterjedtsége alapozhatja meg. ${ }^{16}$ A bírság összegének meghatározásakor a GVH enyhítő körülményként veheti figyelembe, ha a határozat meghozatalát megelőzően bármilyen peren kívüli eljárásban (alternatív vitarendezésben) létrejött megállapodás alapján a jogsértő vállalkozás kártérítést fizetett a versenyjogi jogsértés károsultja részére. ${ }^{17} \mathrm{~A}$ bírság meghatározásáról a GVH egy külön közleményt adott ki, amely előzetesen megismerhetővé teszi a vállalkozások számára a bírságkiszabási szempontokat. ${ }^{18}$ A GVH közleményének a célja éppen a jogalkalmazási gyakorlata alapjainak ismertetése, ezen keresztül a jogalkalmazás kiszámíthatóságának növelése, valamint annak rögzítése, hogy GVH milyen - önmagára nézve kötelező tartalommal tölti meg a jogszabály rendelkezéseit, összefoglalva a múltban kialakult, illetve a jövőben követni kívánt jogalkalmazási gyakorlatot. ${ }^{19}$ A GVH közleménye a GVH-t köti, attól csak kivételesen, akkor és annyiban térhet el, amennyiben a közlemény szempontrendszerének konkrét esetre alkalmazása

15 A tisztességtelen piaci magatartás és a versenykorlátozás tilalmáról szóló 1996. évi LVII. törvény (továbbiakban: Tpvt.) 76. $\$(1)$ bekezdés.

16 Tpvt. 78. $\$(3)$ bekezdés.

17 Tpvt. 78. $\$(10)$ bekezdés.

18 A Gazdasági Versenyhivatal elnökének és a Gazdasági Versenyhivatal Versenytanácsa elnökének 12/2017. közleménye a fogyasztóvédelmi típusú ügyekben kiszabott bírság meghatározásának szempontjairól.

19 1392/B/2007. AB határozat III.1. pont. 


\section{TisZTeSSÉGTELEN KERESKEDELMI GYAKORLATOK - MagYARORSZÁG}

jogszabályba ütközne, s a közleménytől való eltérést a GVH-nak részletesen indokolnia is kell. ${ }^{20}$

Sajátos szabályok érvényesülnek a kis- és középvállalkozások bírságolása esetén. 2020 előtt általános szabályként előírásra került, hogy a hatósági ellenőrzést végző szervek a kis- és középvállalkozásokkal szemben az első esetben előforduló jogsértés esetén bírság kiszabása helyett figyelmeztetést alkalmaznak. Egyes esetekben nem volt lehetőség a bírságtól való eltekintésre, így például ha a tizennyolcadik életévüket be nem töltött személyek védelmét célzó jogszabályi rendelkezés megsértésére került sor, vagy a jogsértésre a személyeknek koruk, hiszékenységük, szellemi vagy fizikai fogyatkozásuk miatt különösen kiszolgáltatott, egyértelműen azonosítható csoportjához tartozó személlyel szemben került sor. ${ }^{21} \mathrm{Az}$ MNB és a GVH eljárásaiban ezt a rendelkezést nem kellett alkalmazni. ${ }^{22}$ A GVH a kis- vagy középvállalkozással szemben az első esetben előforduló jogsértés esetén bírság kiszabása helyett figyelmeztetést is alkalmazhatott, ha a vállalkozásnak az eljárás során tanúsított magatartása alapján alaposan feltételezhető volt, hogy a vállalkozás jövőbeni magatartásának jogszerűsége, az újabb jogsértés elkövetésétől való tartózkodása így is biztosítható. A GVH nem tekinthetett el a bírságtól, ha a jogsértésre a személyeknek koruk, hiszékenységük, szellemi vagy fizikai fogyatkozásuk miatt különösen kiszolgáltatott, egyértelmüen azonosítható csoportjához tartozó személlyel szemben került sor. ${ }^{23} \mathrm{Ha}$ a fogyasztóvédelmi hatóság járt el, akkor - ha a kis- és középvállalkozásokról, fejlődésük támogatásáról szóló törvény eltérően nem rendelkezik - minden esetben bírságot szabott ki, ha például a jogsértés a fogyasztók széles körét érintette. ${ }^{24}$

2020. január 1-jétől hatályát veszítette a korábbi, a kis-és középvállalkozások számára kedvező általános szabályozás, ugyanakkor egyebekben a kis- és középvállalkozásokról, fejlődésük támogatásáról szóló 2004. évi XXXIV. törvény $12 / \mathrm{A}$. $\$$-a alapján a fogyasztókkal szembeni tisztességtelen kereskedelmi gyakorlat ügyében eljáró hatóságok esetében az eddigi szabályok alkalmazandók a továbbiakban is:

- a fogyasztóvédelmi hatóság minden esetben bírságot szab ki, ha például a jogsértés a fogyasztók széles körét érinti vagy a tizennyolcadik

20 Kúria Kfv.III.37.697/2011/9. (Vj/112/2006.)

21 A kis- és középvállalkozásokról, fejlődésük támogatásáról szóló 2004. évi XXXIV. törvény 12/A. \$-a.

22 MNBtv. 57/A. \$

23 Tpvt. 78. $\$(8)$ és (9) bekezdés.

24 Fgytv. 47/C. \$ (5) bekezdés. 
életévüket be nem töltött személyek védelmét célzó jogszabályi rendelkezés megsértésére került sor, ${ }^{25}$

- az MNB eljárásai esetében külön rendelkezés nincs a kis- és középvállalkozások bírságolására,

- a GVH esetén továbbra is él a szabály, mely szerint a kis- vagy középvállalkozással szemben az első esetben előforduló jogsértés esetén a GVH bírság kiszabása helyett figyelmeztetést is alkalmazhat, ha a vállalkozásnak az eljárás során tanúsított magatartása alapján alaposan feltételezhető, hogy a vállalkozás jövőbeni magatartásának jogszerűsége, az újabb jogsértés elkövetésétől való tartózkodása így is biztosítható, azzal, hogy a GVH nem tekinthet el a bírságtól, ha a jogsértésre a személyeknek koruk, hiszékenységük, szellemi vagy fizikai fogyatkozásuk miatt különösen kiszolgáltatott, egyértelműen azonosítható csoportjához tartozó személlyel szemben került sor.

Összességében a 2005/29/EK irányelv módosítására tekintettel a hatóságok bírságolására vonatkozó előírások módosítása mutatkozik szükségesnek:

- egyrészt a figyelembe veendő szempontok pontosítása érdekében,

- másrészt a kis- és középvállalkozásokra irányadó különös szabályokkal összefüggésben, mivel a szabályozás jogértelmezési kérdéseket vet fel, így például az uniós kis- és középvállalkozás esetében nem alkalmazandó, ezáltal különbséget tesz a honos és nem honos jogsértők közötti szankcionálásban a jogsértéstől függetlenül, illetőleg a figyelmeztetés intézménye nem minden esetben felel meg a szankciókkal szemben támasztott azon követelménynek, hogy legyen arányos a jogsértéssel és kellő visszatartó erővel bírjon.

\subsection{Bírság összegének meghatározása}

Ha a hatáskörrel rendelkező hatóság és/vagy bíróság tisztességtelen kereskedelmi gyakorlat esetén pénzbírságot szab ki, jogszabály meghatározza a bírság legmagasabb összegét. A gyakorlatban a ténylegesen kiszabott bírságok összege általában nem közelíti meg a maximális mértéket, de egyes speciális ügyekben (pl. gyógyhatással kapcsolatos valótlan állításokat tartalmazó reklámok esetén)

25 Fgytv. 47/C. $\$(5)$ bekezdés. 


\section{TiszTESSÉGTELEN KERESKEDELMI GYAKORLATOK - MagYARORSZÁG}

a bírság összege elérte azt. A kiszabott bírságok mértékének maximuma nem teljeskörűen feleltethető meg a 2005/29/EK irányelv módosítása szerinti mértéknek, így átgondolandó, milyen kedvezményekben részesüljenek a jogsértő kis- és középvállalkozások.

A fogyasztóvédelmi hatóság által kiszabott bírság összege 15 ezer forinttól:

- a számvitelről szóló törvény hatálya alá tartozó, 100 millió forintot meghaladó éves nettó árbevétellel rendelkező, a kis- és középvállalkozásoknak nem minősülő vállalkozás esetében a vállalkozás éves nettó árbevételének 5\%-áig, de legfeljebb 500 millió forintig, illetve a fogyasztók széles körének testi épségét, egészségét sértő vagy veszélyeztető, továbbá a fogyasztók széles körének jelentős vagyoni hátrányt okozó jogsértés esetén legfeljebb 2 milliárd forintig terjedhet,

- a fenti körbe nem tartozó vállalkozás esetében 500 ezer forintig, illetve a fogyasztók széles körének testi épségét, egészségét sértő vagy veszélyeztető, továbbá a fogyasztók széles körének jelentős vagyoni hátrányt okozó jogsértés esetén a vállalkozás éves nettó árbevételének 5\%-áig, a számviteli törvény hatálya alá nem tartozó vállalkozás esetén 5 millió forintig terjedhet ${ }^{26}$ (külön szabályok vonatkoznak az elektronikus kereskedelmi szolgáltatást nyújtó vállalkozás bírságaira).

Az MNB által kiszabott bírság összege 15 ezer forinttól

- a számvitelről szóló törvény hatálya alá tartozó, 100 millió forintot meghaladó éves nettó árbevétellel rendelkező szervezet esetében az éves nettó árbevételének 5 \%-áig, de legfeljebb 100 millió forintig, illetve a fogyasztók széles körének jelentős vagyoni hátránnyal fenyegető helyzetet okozó jogsértés esetén legfeljebb 2 milliárd forintig terjedhet,

- a fenti körbe nem tartozó vállalkozás esetében 5 millió forintig, illetve a fogyasztók széles körének jelentős vagyoni hátránnyal fenyegető helyzetet okozó jogsértés esetén a szervezet vagy személy éves nettó árbevételének $10 \%$-áig, amennyiben ez az 5 millió forintot meghaladja, a számvitelről szóló törvény hatálya alá nem tartozó szervezet vagy személy esetében legfeljebb 15 millió forintig terjedhet. ${ }^{27}$ 
A GVH által kiszabott bírság maximális mértéke a vállalkozás, illetve azon - a határozatban azonosított - vállalkozáscsoport a határozat meghozatalát megelőző üzleti évben elért nettó árbevételének 10\%-a lehet, amelynek a bírsággal sújtott vállalkozás a tagja. ${ }^{28} \mathrm{Az}$ elmúlt években a GVH több esetben szabott ki a törvényi maximumot elérő vagy ahhoz közeli mértékü bírságot, elsősorban gyógyhatás valótlan állítása, megtévesztő egészségre ható állítás, illetve kiszolgáltatott fogyasztókkal szemben tanúsított jogsértés esetén. ${ }^{29}$

A fogyasztóvédelmi hatóság és az MNB által kiszabott bírságok mértékére vonatkozó elöírásokat összhangba kell majd hozni a 2005/29/EK irányelv módosításával.

\section{A tisztességtelen kereskedelmi gyakorlat károsultjai kárának megtérítése hatósági eljárásban}

A tisztességtelen kereskedelmi gyakorlat ügyében a hatáskörrel rendelkező hatóság fó szabály szerint nem kötelezheti a jogsértő vállalkozást arra, hogy megtérítse a tisztességtelen kereskedelmi gyakorlat károsultjainak a kárát. A joggyakorlatban kivételesnek minősíthető az a döntés, amelyben a hatóság megállapította a fogyasztókkal szembeni tisztességtelen kereskedelmi gyakorlat tilalmának megsértését, bírságot szabott ki, továbbá rögzítette, hogy a jogsértő kereskedelmi gyakorlat a fogyasztók meghatározott köreinek anyagi hátrányokat is okozott és ezért kárenyhítési következményekkel bíró kötelezéseket állapított meg határozatában. ${ }^{30}$

A hatáskörrel rendelkező hatóság előtti eljárás során a vállalkozás vállalhatja a kár megtérítését, amelynek vállalására, illetve előírására:

- egy hatósági szerződésben kerülhet sor a fogyasztóvédelmi hatóság és az MNB előtti eljárás esetében,

- egy kötelezettségvállalási nyilatkozat megtételével és az abban vállalt kötelezettségek teljesítését előíró határozat meghozatalával kerülhet sor a GVH előtti eljárásban.

28 Tpvt. 78. $\$(1 \mathrm{~b})$ bekezdés.

29 Lásd pl. a Vj/5/2011. számú ügyet. A GVH bírságolási gyakorlatáról, az irányadó szabályozásról lásd Bacher G. et al.: Kommentár a tisztességtelen piaci magatartás és versenykorlátozás tilalmáról szóló 1996. évi LVII. törvényhez, kiadta a Gazdasági Versenyhivatal, Budapest, 2014. 630-646.

$30 \mathrm{Vj} / 64 / 2015$. ügyben hozott határozat, lásd különösen a 244-250. pontokat. A GVH határozatának bírósági felülvizsgálata során a Kúria Kf.II.37.969/2018/10. számú ítéletében megállapította, hogy a GVH határozatában foglalt kötelezések a kompenzációt szolgálták, nem szankcióként kerültek kiszabásra. 


\section{TiszTeSSÉGTELEN KERESKEDELMi GYAKORLATOK - MaGYARORSZÁG}

A fogyasztóvédelmi hatóság a jogsértés megszüntetése érdekében határozathozatal helyett hatósági szerződést köthet azzal az ügyféllel, aki vállalja, hogy felhagy a jogsértő magatartással, és magatartását a hatósági szerződésben meghatározott módon hozza összhangba a fogyasztóvédelmi rendelkezésekkel. Ebben az esetben a fogyasztóvédelmi hatóság nem szabhat ki bírságot a fogyasztóvédelmi hatósággal hatósági szerződést kötő ügyféllel szemben a szerződésben megállapított teljesítési határidőn belül azon jogsértés miatt, amelynek megszüntetése érdekében a szerződés megkötésére sor került. ${ }^{31}$

Az MNB a fogyasztóvédelmi ellenőrzési eljárás során feltárt jogsértés megszüntetése érdekében határozathozatal helyett hatósági szerződést köthet azzal az ügyféllel, aki vállalja, hogy felhagy a jogsértő magatartással és magatartását a hatósági szerződésben meghatározott módon hozza összhangba a vonatkozó jogszabályok rendelkezéseivel. Erről a szerződésről az MNB hirdetményt tesz közzé a honlapján vagy az általa célszerűnek tartott egyéb módon, ismertetve a kötelezettségvállalás tartalmát. ${ }^{32}$

A hatósági szerződés tartalmazza egyebek között a felek által vállalt kötelezettségeket és biztosított jogokat. ${ }^{33}$ A hatósági szerződés megkötésére a fogyasztóvédelmi hatóság és az MNB nem köteles, ugyanakkor a vállalkozások előtt nem ismertek annak szempontjai, hogy mi alapján dönt a hatóság arról, hogy köt-e hatósági szerződést, vagy sem.

A GVH hatósági szerződés megkötése helyett a kötelezettségvállalást alkalmazhat: a vizsgált magatartás tekintetében a vállalkozás kötelezettséget vállalhat arra, hogy magatartását meghatározott módon összhangba hozza az alkalmazandó jogszabályi rendelkezésekkel, és ha a közérdek hatékony védelme ilyen módon is biztosítható, az eljáró versenytanács határozatában kötelezővé teheti a vállalás teljesítését anélkül, hogy a határozatban a jogsértés megvalósulását vagy annak hiányát megállapítaná. $\mathrm{Ha}$ az ügyfél a vizsgált magatartással időközben felhagyott, a magatartás ismételt tanúsításának elkerülését biztosító átlátható és ellenőrizhető magatartási szabályok betartására vállalható kötelezettség. ${ }^{34}$ A kötelezettségvállalás elfogadása esetén tehát a GVH nem állapít meg jogsértést és nem szab ki bírságot sem. A GVH nem köteles elfogadni a vállalkozás kötelezettségvállalási nyilatkozatát. A döntés során figyelembe vett

31 Fgytv. 47. $\$(6)$ és (7) bekezdés.

32 MNBtv. $95 . \$$

33 Az általános közigazgatási rendtartásról szóló 2016. évi CL. törvény 92. \$ (2) bekezdés.

34 Tpvt. 75. $\$(1)$ bekezdés. 
szempontok a GVH közleményéből megismerhetők a vállalkozások számára. ${ }^{35}$ Kiemelendő, hogy a kár megtérítésének vállalása akkor is hatással lehet a GVH döntésére, ha az eljárás nem kötelezettségvállalás elfogadásával zárul. A bírság összegének meghatározásakor a GVH enyhítő körülményként veheti figyelembe, ha a határozat meghozatalát megelőzően bármilyen peren kívüli eljárásban (alternatív vitarendezésben) létrejött megállapodás alapján a jogsértő vállalkozás kártérítést fizetett a versenyjogi jogsértés károsultja részére. ${ }^{36}$

A fogyasztóvédelmi hatóság és az MNB hatósági szerződései, illetőleg a GVH kötelezettségvállalása megfeleltethető a 2017/2394/EU rendelet szerinti kötelezettségvállalásnak.

\section{Hatósági eljárás a fogyasztó kezdeményezésére}

A tisztességtelen kereskedelmi gyakorlat ügyében benyújtott fogyasztói panasz (bejelentés) esetén a hatáskörrel rendelkező hatóság (a fogyasztóvédelmi hatóság, az MNB vagy a GVH) nem köteles automatikusan eljárást indítani a vállalkozással szemben, mérlegelheti, hogy fennállnak-e az eljárás megindításának feltételei, így mindenekelőtt azt, hogy valószínűsíthető-e a jogsértés. Az eljárás megindításáról való döntés során a hatóságok által figyelembe vett további, érdemi szempontok nem kerülnek előzetesen meghatározásra, ezek a szempontok esetről esetre változhatnak. Csak általános szabályok vannak, így a fogyasztók számára sem ismerhetők meg előzetesen a hatóság által figyelembe vett szempontok, s ezzel kapcsolatban nyilvános támpontok sem állnak rendelkezésükre. Mindez azt eredményezi, hogy a fogyasztók előtt pontosan nem ismert, milyen szempontok szerint hoz döntést a hatóság és a fogyasztó milyen módon befolyásolhatja a maga számára kedvezően az ügyindításról való döntést.

Így a fogyasztók előtt csupán az eljárás megindítására vonatkozó, jogszabályban meghatározott elöírások lehetnek ismertek, mégpedig:

- az eljárás a jogsértő kereskedelmi gyakorlat megvalósulását követő három éven túl nem indítható meg, ${ }^{37}$

35 A GVH elnökének és a GVH Versenytanácsa elnökének 6/2014. számú közleménye a fogyasztókkal szembeni tisztességtelen kereskedelmi gyakorlat tilalmának feltételezett megsértése tárgyában indult eljárásokban tett kötelezettségvállalásról. A kötelezettségvállalásokkal kapcsolatos gyakorlatáról lásd Bacher G. et al.: Kommentár a tisztességtelen piaci magatartás és versenykorlátozás tilalmáról szóló 1996. évi LVII. törvényhez. Gazdasági Versenyhivatal, Budapest, 2014., 611-619.

36 Tpvt. 78. $\$(10)$ bekezdés.

37 Fttv. 13. $\$$ 
- a fogyasztó fogyasztóvédelmi hatóság részére benyújtott kérelmének tartalmaznia kell a feltételezett jogsértéssel érintett üzlet címét vagy a kifogásolt magatartás elkövetésének helyét, a beadvány tárgyának rövid leírását a rendelkezésre álló dokumentumokkal alátámasztva, ideértve különösen a vállalkozásnak a fogyasztó megkeresésére adott válaszlevelét, a szóbeli panaszról felvett jegyzőkönyvet, vagy postai úton benyújtott panasz esetében a feladás igazolását szolgáló dokumentumot, ${ }^{38}$

- az MNB esetén a fogyasztóvédelmi eljárás kérelemre történő megindításának feltétele, hogy a fogyasztó a pénzügyi szervezetnél panaszát már korábban előterjesztette, azonban a panaszára nem kapott választ vagy annak kivizsgálása nem a jogszabályi előírásoknak megfelelően történt meg, illetve a pénzügyi szervezet válaszából egyéb, fogyasztói jogot sértő körülményt vélelmezhető, ${ }^{39}$

- a GVH akkor rendel el vizsgálatot, ha az adott kereskedelmi gyakorlat a GVH hatáskörébe tartozik és a magatartás valószínűsíthetően sérti a tisztességtelen kereskedelmi gyakorlat tilalmát. ${ }^{40}$ A GVH eljárásával összefüggésben szükséges emlékeztetni arra, hogy míg általában egy versenyfelügyeleti (például egy kartelleket vizsgáló) eljárás megindítása előtt a GVH egy közérdek-tesztet végez el, mérlegeli, hogy a közérdek védelme szükségessé teszi-e a versenyfelügyeleti eljárás lefolytatását, addig az Fttv. rendelkezéseinek sérelme miatt indult eljárásokban a versenyfelügyeleti eljárás indulásakor nem alkalmazható ez a közérdekteszt. Az Fttv. rendelkezéseinek sérelmét felvető magatartások esetében nincs helye a versenyfelügyeleti eljárás indításakor, illetve folytatása esetében másfajta (közérdekszerü) mérlegelésnek sem. Ezekben az esetekben az a vélelem, hogy fennáll a közérdek védelmének szükségessége.

A figyelembe vett szempontokról a hatóságok által a panasz/bejelentés benyújtására kidolgozott űrlapok adnak még közvetetten tájékoztatást, ugyanakkor részleteiben azokból sem ismerhető meg a fogyasztók számára, hogy a hatóságok érdemben milyen szempontokat vesznek figyelembe mérlegelésük során. ${ }^{41}$

\footnotetext{
38 Fgytv. 46/A. $\$$

39 MNBtv. 81. $\$(3)$ bekezdés.

40 Fttv. 26. $\$(1)$ bekezdés.

41 A GVH panaszokkal és bejelentésekkel kapcsolatos gyakorlatáról lásd Bacher: i.m., 450-471.
} 
Mindenképpen kívánatos lenne, ha a fogyasztók számára áttekinthetőbb legyen a hatóságok eljárása, így különösen az, hogy milyen szempontok figyelembe vételével döntenek az eljárás megindításáról vagy annak mellőzéséről. Ezek ismeretében a fogyasztók (és érdekképviseleti szervezeti) hatékonyabban tudnának hatósági eljárásokat kezdeményezni a tisztességtelen kereskedelmi gyakorlatot tanúsító vállalkozásdokkal szemben.

\section{A fogyasztók közvetlen fellépése a tisztességtelen kereskedelmi gyakorlatokkal szemben}

A fogyasztók bírósághoz és hatósághoz egyaránt fordulhatnak a tisztességtelen kereskedelmi gyakorlatok miatt, ezt nem kell, hogy megelőzze egy hatósági eljárás. Nincs semmilyen kötelező sorrendiség az igényérvényesítés vonatkozásában, így a fogyasztó fellépését, adott esetben bírósághoz fordulását nem kell megelőznie egy hatósági eljárásnak. Mindazonáltal egy jogsértést megállapító hatósági határozat mindenképpen elősegíti a magánjogi jogérvényesítés eredményességének esélyét. ${ }^{42}$

A fogyasztó tehát közvetlenül bírósághoz is fordulhat, illetve, ha az adott kereskedelmi gyakorlattal összefüggésben megindításra került egy hatósági eljárás, akkor az sem zárja ki, hogy a sérelmet szenvedett fogyasztó a kereskedelmi gyakorlat tisztességtelenségére alapított polgári jogi igényét közvetlenül a bíróság előtt érvényesítse. ${ }^{43} \mathrm{Ha}$ azonban valamely perben az Fttv. valamely rendelkezése alkalmazásának szükségessége merül fel, akkor a bíróság haladéktalanul értesíti a hatáskörrel rendelkező hatóságot. A hatóság észrevételt tehet az eljárás során, amely a bíróságot nem köti. Ha a bíróság szükségesnek ítéli, akkor a hatóság a bíróság felhívásában meghatározott határidőn belül köteles az Fttv. rendelkezésének alkalmazásával kapcsolatos jogi álláspontjáról a bíróságot tájékoztatni. Ha a hatóság a per bármely szakaszában arról tájékoztatja a bíróságot, hogy az érintett ügyben versenyfelügyeleti eljárást indított, a bíróság a peres eljárást a hatóság eljárásában hozott határozat elleni keresetindítási határidő lejártáig, illetve keresetindítás esetében a bírósági eljárás jogerős befejezéséig felfüggeszti, kivéve, ha a hatóság az ügyben már véglegessé vált határozatot hozott vagy az

42 Erre mutat rá Hajnal Zs.: A fogyasztóvédelem helye a magyar jogrendszerben. In: Homicskó Á. O. Szuchy R. (szerk.): Studia in honorem Péter Miskolczi-Bodnár. Károli Gáspár Református Egyetem Állam- és Jogtudományi Kar, Budapest, 2017. 249.

43 Fttv. 15. $\$(1)$ bekezdés. 


\section{TiszTESSÉGTELEN KERESKEDELMI GYAKORLATOK - MagYARORSZÁG}

eljárását egyébként véglegesen lezárta, és a hatóság döntését bíróság előtt nem támadták meg, vagy a bírósági eljárás már jogerősen lezárult. Ez utóbbi esetben a hatóság megküldi a bíróságnak a véglegessé vált döntését, illetve a jogerôs bírósági határozatot. Ha az érintett ügyben a hatóság eljárt, a bíróság a hatóság keresettel nem támadott határozatának, illetve - ha a határozatot megtámadták - a bíróság határozatának a jogsértést megállapító részéhez kötve van. ${ }^{44}$

\section{A tisztességtelen kereskedelmi gyakorlat károsultjai kárának megtérítése bírósági eljárásban}

A tisztességtelen kereskedelmi gyakorlat károsultjainak lehetőségük van kártérítést követelni bírósági eljárás keretében. Ugyanakkor ennek nem alakult ki gyakorlata, mivel ezzel a lehetőséggel lényegében nem élnek a károsultak. Így, noha adott a csoportos igényérvényesítés lehetősége, ezen a téren sem beszélhetünk általános gyakorlatról.

A hatósági eljárás lefolytatása nem zárja ki azt, hogy a sérelmet szenvedett fél a kereskedelmi gyakorlat tisztességtelenségére alapított polgári jogi igényét közvetlenül a bíróság előtt érvényesítse. A károsultak kártérítési igényérvényesítésének sikerességét segítheti elő, ha egy hatósági eljárásban (illetve a hatósági döntéssel szembeni bírósági eljárásban) megállapították, hogy a vállalkozás tisztességtelen kereskedelmi gyakorlatot tanúsított, jogsértést valósított meg, hiszen ha az érintett ügyben a hatóság eljárt, a bíróság a hatóság keresettel nem támadott határozatának, illetve - ha a határozatot megtámadták a bíróság határozatának a jogsértést megállapító részéhez kötve van. ${ }^{45}$ Ugyanakkor továbbra is a károsultakra hárul a kárnak (és a kár mértékének) a bizonyítása. Míg a kartellel okozott versenyjogi jogsértés esetén az ellenkező bizonyításáig vélelmezni kell, hogy a versenyjogi jogsértés a jogsértő vállalkozás által alkalmazott árat tíz százaléknyi mértékben befolyásolta, ${ }^{46}$ addig a fogyasztókkal szembeni tisztességtelen kereskedelmi gyakorlatok kapcsán ilyen jellegű szabály nem segíti a károsultak igényérvényesítését.

44 Fttv.15. $\$(3)$ bekezdés és Tpvt. 88/B. $\$(1)-(8)$ bekezdés.

45 Fttv.15. $\$(3)$ bekezdés és Tpvt. 88/B. $\$(8)$ bekezdés.

46 Tpvt. 88/G. $\$(6)$ bekezdés. 


\section{A fogyasztói érdekek képviseletét ellátó egyesületek fellépése a tisztességtelen kereskedelmi gyakorlatokkal szemben}

A fogyasztói érdekek képviseletét ellátó egyesületek is felléphetnek a fogyasztókat megcélzó tisztességtelen kereskedelmi gyakorlatokkal szemben: hatósághoz fordulhatnak, illetve bírósági eljárást kezdeményezhetnek. A fogyasztói érdekek ily módon történő védelmének jelentőségét csökkenti, hogy Magyarországon kevés fogyasztói érdekek képviseletét ellátó egyesület működik.

Az elmúlt időszakban a fogyasztók érdekképviseleti szervezetei ritkán éltek azzal a lehetőséggel, hogy hatósághoz vagy bírósághoz forduljanak a vállalkozások fogyasztókkal szembeni tisztességtelen kereskedelmi gyakorlatával összefüggésben.

A hatóságok elvileg nem tesznek különbséget a panaszosok (bejelentők) között, így ha a fogyasztók érdekképviseleti szervezeteik hatósághoz fordulnak, akkor ennek sikeressége azonos mértékű volt azzal, mint amikor a fogyasztók közvetlenül fordultak a hatóságokhoz.

E szervezetek tisztességtelen kereskedelmi gyakorlat ügyében tett panasza esetén sem köteles a hatáskörrel rendelkező hatóság automatikusan eljárást indítani a vállalkozással szemben, mérlegelheti, hogy fennállnak-e az eljárás megindításának feltételei. A hatóság által a döntés során figyelembe vett szempontok előre pontosan nem meghatározottak, csak általános szabályok vannak, így a fogyasztók érdekképviseleti szervezetei fogyasztók számára sem ismerhetők meg előzetesen a hatóság által figyelembe vett szempontok.

A fogyasztókkal szembeni tisztességtelen kereskedelmi gyakorlat tilalmának megsértése esetén eljáró három hatóság eljárását illetően az alábbiak emelendők ki:

- a fogyasztóvédelmi hatóság eljárásában az általuk védett fogyasztói érdekek védelme körében a fogyasztói érdekek képviseletét ellátó egyesületeket az ügyfél jogai illetik meg. ${ }^{47} \mathrm{Ha}$ a fogyasztóvédelmi hatóság eljárást nem a fogyasztói érdekek képviseletét ellátó egyesület, hanem más kezdeményezte, akkor ebben az eljárásban az ügyfél jogai csak akkor illetik meg a fogyasztói érdekek képviseletét ellátó egyesület, ha az eljárásban vizsgált jogsértés a fogyasztók széles körét érinti. ${ }^{48}$

47 Fgytv. 46. $\$(2)$ bekezdés a) pont.

48 Fgytv. 46. $\$(2 \mathrm{a})$ bekezdés. 
- az MNB előtt az általuk védett érdekek védelme körében az ügyfél jogai illetik meg a fogyasztóvédelmi irányelveket átültető jogszabályi rendelkezések megsértésére hivatkozással az EGT bármely más államának joga alapján létrejött azon feljogosított egységeket is, amelyek a fogyasztói érdekek védelme érdekében a jogsértés megszüntetésére irányuló eljárásokról szóló, 2009. április 23-i 2009/22/EK európai parlamenti és tanácsi irányelv 4. cikk (3) bekezdése alapján az Európai Unió Hivatalos Lapjában közzétett jegyzékben szerepelnek. ${ }^{49}$

- a GVH hatáskörébe tartozó jogsértés miatt bárki bejelentéssel vagy panasszal élhet a GVH-nál, ${ }^{50}$ így a fogyasztói érdekek képviseletét ellátó egyesület is.

A hatósági eljárás kezdeményezése mellett a fogyasztói érdekek képviseletét ellátó egyesület pert is indíthat a fogyasztók polgári jogi igényeinek érvényesítése iránt az ellen, aki esetében a fogyasztóvédelmi hatóság véglegesen megállapította, hogy fogyasztókkal szembeni tisztességtelen kereskedelmi gyakorlatot tanúsított, ha a jogsértő tevékenység a fogyasztók széles, személyében nem ismert, de a jogsértés körülményei alapján meghatározható körét érinti (közérdekű igényérvényesítés). ${ }^{51}$ A fogyasztói érdekek képviseletét ellátó egyesület továbbá keresetindítási joggal is rendelkezik, ha a vállalkozás jogszabálysértő tevékenysége a fogyasztók széles, személyében nem ismert, de a jogsértés körülményei alapján meghatározható körét érinti vagy jelentős nagyságú hátrányt okoz, és az eljárás a bíróság hatáskörébe tartozik (közérdekü keresetindítás). ${ }^{52}$

49 MNBtv. 82. $\$(1)$ bekezdés.

50 Tpvt. 43/G. $\$(1)$ bekezdés.

51 Fgytv. 38. $\$$

52 Fgytv. 39. $\$$ Közérdekű kereset indítható például a fogyasztó és a vállalkozás közötti szerződés részévé váló tisztességtelen általános szerződési feltétel érvénytelenségének megállapítása iránt az általa védett fogyasztói érdekek körében, lásd a Polgári Törvénykönyvről szóló 2013. évi V. törvény 6:105. \$ (1) bekezdés e) pont. A kollektív igényérvényesítés egyes kérdéseiről lásd például: Bihari E.: Lehetőségek és kihívások - Kollektív fogyasztói jogérvényesítés Magyarországon. In: Szikora V. - Árva Zs. (szerk.): A fogyasztók védelmének üj irányai és kihivásai a XXI. században. Debreceni Egyetem Állam- és Jogtudományi Kar, Debrecen, 2018. 147-156., Hajnal Zs. - Bihari E.: A fogyasztói kollektív érdekvédelem új irányai az Európai Unióban és Magyarországon. In: Szikora V. - Árva Zs. (szerk.): Újratervezés - Fogyasztói szabályozási modellek, digitalizáció, adatvédelem. Debreceni Egyetem Állam- és Jogtudományi Kar, Debrecen, 2019. 49-71. 


\section{A magatartási kódexek szerepe}

Léteznek olyan magatartási kódexek, amelyek segítségével a vállalkozások hatékonyabban alkalmazhatják a tisztességtelen kereskedelmi gyakorlat tilalmára vonatkozó előírásokat. Ezek az előírások ugyanakkoráltalában egy átfogóbb etikai kódex részeként jelennek meg, illetőleg van, amikor kifejezetten a kereskedelmi kommunikációkra vonatkozik (például a Gyógyszer-kommunikáció Etikai Kódexe, amelynek célja az etikus kereskedelmi gyakorlatok szabályainak lefektetése és azok betartásának elérése a gyógyszeripar vállalatainak egymásra gyakorolt hatásával, magatartásával). Az ilyen etikai kódexek alapján kérelemre jár el az adott szervezet. Az etikai kódex alapján lefolytatott eljárásnak nincs közvetlen hatása a tisztességtelen kereskedelmi gyakorlatot érintő hatósági és/ vagy bírósági eljárásokra, azzal, hogy a hatóság vagy bíróság bizonyítékként figyelembe veheti az etikai eljárásban született döntést, úgy a jogsértés, mint a bírság mértéke körében.

Magyarországon csak néhány olyan magatartási kódex létezik, amelyek a 2005/29/EK irányelv szerinti magatartási kódexnek minősíthetők. A vállalkozások óvatosságot részben az is magyarázhatja, hogy a magyar joggyakorlatban nem kellően tisztázottak a magatartási kódexekkel kapcsolatos versenyjogi kérdések, így különösen az, hogy milyen esetben minősülhet vállalkozások közötti jogsértő megállapodásnak (összehangolt magatartásnak) egy magatartási kódex elfogadása, alkalmazása, az ahhoz történő csatlakozás.

A magyar gyakorlatból a lakosság részére hitelt nyújtó pénzügyi szervezetek ügyfelekkel szembeni tisztességes magatartásáról szóló (az MNB közreműködésével létrejött) magatartási kódexre, illetve az Önszabályozó Reklám Testület és a Nemzeti Média- és Hírközlési Hatóság Médiatanácsa közötti közigazgatási szerződésre és az ahhoz kapcsolódó magatartási kódexre hívjuk fel a figyelmet.

Az MNB és a Magyar Bankszövetség egyeztetésének eredményeként jött létre a 2010. január 1-jén hatályba lépett, a lakosság részére hitelt nyújtó pénzügyi szervezetek ügyfelekkel szembeni tisztességes magatartásáról szóló (2015-ben módosított) Magatartási Kódex. A Magatartási Kódex részben érinti a fogyasztókkal szembeni kereskedelmi gyakorlatokat is. Az MNB egyrészt az Fttv. alapján ellenőrzi a magatartási kódex betartását, másrészt az ágazati szabályozás, a hitelintézetekről és a pénzügyi vállalkozásokról szóló 2013. évi CCXXXVII. törvény alapján, tekintettel arra, hogy a magatartási kódexben szerepel az 


\section{TiszTeSSÉGTELEN KERESKEDELMi GYAKORLATOK - MaGYARORSZÁG}

is, a magatartási kódex aláírói kötelezettséget vállalnak arra, hogy általános szerződési feltételeiket magában foglaló üzletszabályzataikban megjelenítik, hogy a magatartási kódexnek kötelező érvénnyel alávetették magukat. Az MNB (illetve jogelődje) több döntésében megállapította az Fttv. magatartási kódexre vonatkozó rendelkezésének a megsértését.

AzÖnszabályozó Reklám Testület és a Nemzeti Média-és Hírközlési Hatóság Médiatanácsa 2011-ben közigazgatási szerződést kötött, amelyben a Médiatanács felhatalmazta az Önszabályozó Reklám Testületet arra, hogy - nem hatósági hatáskörként - a Médiatanács hatósági jogalkalmazását megelőző önigazgatási feladatot lásson el a szerződésben foglaltaknak megfelelően. A szerződés melléklete a társszabályozási magatartási kódex, amely valamennyi magyar joghatóság alatt álló, nyomtatott sajtótermékben, internetes sajtótermékben és lekérhető médiaszolgáltatásban kereskedelmi közleményt közzétevő vállalkozás gyakorlati, szakmai normagyűjteménye. Kiterjed - a politikai reklámok kivételével - a közigazgatási szerződés keretein belül a Magyarországon közzétett valamennyi nyomtatott és internetes sajtótermékben, valamint lekérhető médiaszolgáltatásban közzétett kereskedelmi közleményre (ideértve a társadalmi célú hirdetést és a támogatást is, ide nem értve a termék megjelenítést, valamint a műsorszámmal egyidejűleg történő támogatás közzétételét), azok megjelenési formájától függetlenül. Hatálya kiterjed a műsorterjesztőre, a médiaszolgáltatóra, és a kiegészítő médiaszolgáltatást nyújtóra, valamint a sajtótermék kiadójára. A kódex egyebek között rögzíti, hogy a kereskedelmi közlemény közvetlenül nem szólíthat fel kiskorúakat valamely áru megvásárlására vagy bérbevételére, illetve szolgáltatás igénybevételére. A tilalom a kiskorúakat megcélzó kereskedelmi közlemények azon típusaira vonatkozik, ahol gazdasági cselekményre vonatkozó közvetlen felszólítás történik (például: „vedd meg, legyen a tied!”). A kereskedelmi közlemény közvetlenül nem szólíthat fel kiskorúakat arra, hogy rábeszéljék szüleiket vagy másokat a reklámozott áru megvásárlására vagy szolgáltatás igénybevételére. Az Önszabályozó Reklám Testület állandó vagy eseti bizottsága jár el a kódex szabályainak megsértése esetén. Az eljárás kérelemre indul, illetve a kódexben meghatározott tárgykörökben és ütemezés szerinti átfogó ellenőrzés eredménye alapján hivatalból indulhat. 


\section{Összegzés}

A fogyasztókkal szembeni tisztességtelen kereskedelmi gyakorlatokkal szembeni fellépés Magyarországon elsősorban hatósági eljárások útján történik. Mindenképpen örvendetes lenne, ha az elkövetkező években megerősödne a fogyasztói érdekeket képviselő egyesületek szerepe, továbbá a fogyasztók közvetlen (egyéni és csoportos) igényérvényesítésének jelentősége.

A 2005/29/EK irányelv módosítása szükségessé teszi a hatósági eljárásokra irányadó magyar szabályozás áttekintését. Szükségesnek mutatkozik a jogszabályok módosítása például a fogyasztóvédelmi hatóság és az MNB által kiszabott bírság maximális mértékével összefüggésben. Bízunk benne, hogy az uniós szabályozás változása más vonatkozásban is kedvező hatással lesz a magyar hatóságok eljárására: a 2017/2394/EU rendelet hatékonyabbá teheti a nem magyarországi székhelyü, de magyarországi fogyasztókat megtévesztő vállalkozásokkal szembeni fellépését. 


\section{TisZTESSÉGTELEN KERESKEDELMI GYAKORLATOK - MAgYARORSZÁG}

\section{Forrásjegyzék}

1. Bacher G. et al.: Kommentár a tisztességtelen piaci magatartás és versenykorlátozás tilalmáról szóló 1996. évi LVII. törvényhez. Gazdasági Versenyhivatal, Budapest, 2014., 611-619.

2. Balogh $\mathrm{V}$ :: Az átlagfogyasztó fogalmával kapcsolatos egyes kérdések. In: Fazekas M. (szerk.): Jogi Tanulmányok. Jogtudományi elöadások az Eötvös Loránd Tudományegyetem Állam-és Jogtudományi Kar Doktori Iskoláinak konferenciáján. ELTE Állam- és Jogtudományi Kar Állam- és Jogtudományi Doktori Iskola, Budapest, 2016.

3. Bihari E.: Lehetőségek és kihívások - Kollektív fogyasztói jogérvényesítés Magyarországon. In: Szikora V. - Árva Zs. (szerk.): A fogyasztók védelmének új irányai és kihivásai a XXI. században. Debreceni Egyetem Állam- és Jogtudományi Kar, Debrecen, 2018. 147-156.

4. Hajnal Zs. - Bihari E.: A fogyasztói kollektív érdekvédelem új irányai az Európai Unióban és Magyarországon. In: Szikora V. - Árva Zs. (szerk.): Újratervezés - Fogyasztói szabályozási modellek, digitalizáció, adatvédelem. Debreceni Egyetem Állam- és Jogtudományi Kar, Debrecen, 2019. 49-71.

5. Hajnal Zs.: A fogyasztóvédelem helye a magyar jogrendszerben. In: Homicskó Á. O. - Szuchy R. (szerk.): Studia in honorem Péter MiskolcziBodnár. Károli Gáspár Református Egyetem Állam- és Jogtudományi Kar, Budapest, 2017. 245-251.

6. Lévayné Fazekas J. - LÉvay M.: A fogyasztóvédelem alkotmányossági kérdéseiről és a magyar fogyasztóvédelmi intézményrendszer változásairól. In: Homicskó Á. O. - Szuchy R. (szerk.): Studia in honorem Péter Miskolczi-Bodnár. Károli Gáspár Református Egyetem Állam- és Jogtudományi Kar, Budapest, 2017. 379-387.

7. PApp M.: Kivel szemben tisztességtelen? Gondolatok az európai uniós fogyasztói képről és az Európai Unió Bírósága által biztosított jogvédelem szintjéről. Versenytükör, 2016/1. 28-37.

8. ZavodNyiK J.: Nagykommentár a tisztességtelen kereskedelmi gyakorlatról szóló törvényhez. Wolters Kluwer, Budapest, 2013. 110-123. 
9. Az Európai Parlament és a Tanács 2005/29/EK irányelve (2005. május 11.) a belső piacon az üzleti vállalkozások fogyasztókkal szemben folytatott tisztességtelen kereskedelmi gyakorlatairól, valamint a 84/450/EGK tanácsi irányelv, a 97/7/EK, a 98/27/EK és a 2002/65/EK európai parlamenti és tanácsi irányelvek, valamint a 2006/2004/EK európai parlamenti és tanácsi rendelet módosításáról, HL L 149, 2005.6.11. 22-39.

10. Az Európai Parlament és a Tanács 2009/22/EK irányelve (2009. április 23.) a fogyasztói érdekek védelme érdekében a jogsértés megszüntetésére irányuló eljárásokról, HL L 110., 2009.5.1., 30-36.

11. Az Európai Parlament és a Tanács (EU) 2017/2394 rendelete (2017. december 12.) a fogyasztóvédelmi jogszabályok végrehajtásáért felelős nemzeti hatóságok közötti együttműködésről és a 2006/2004/EK rendelet hatályon kívül helyezéséről, HL L 345., 2017.12.27., 1-26.

12. Az Európai Parlament és a Tanács 2019/2161 irányelve (2019. november 27.) a 93/13/EGK tanácsi irányelvnek, valamint a 98/6/EK, a 2005/29/ EK és a 2011/83/EU európai parlamenti és tanácsi irányelvnek az uniós fogyasztóvédelmi szabályok hatékonyabb végrehajtása és korszerüsítése tekintetében történő módosításáról, HL L 328., 2019.12.18., 7-28.

13. A tisztességtelen piaci magatartás és a versenykorlátozás tilalmáról szóló 1996. évi LVII. törvény

14. A fogyasztóvédelemről szóló 1997. évi CLV törvény

15. A fogyasztókkal szembeni tisztességtelen kereskedelmi gyakorlat tilalmáról szóló 2008. évi XLVII. törvény

16. A kis- és középvállalkozásokról, fejlődésük támogatásáról szóló 2004. évi XXXIV. törvény

17. A Magyar Nemzeti Bankról szóló 2013. évi CXXXIX. törvény

18. A hitelintézetekről és a pénzügyi vállalkozásokról szóló 2013. évi CCXXXVII. törvény

19. Az általános közigazgatási rendtartásról szóló 2016. évi CL. törvény

20. A GVH elnökének és a GVH Versenytanácsa elnökének 6/2014. számú közleménye a fogyasztókkal szembeni tisztességtelen kereskedelmi gyakorlat tilalmának feltételezett megsértése tárgyában indult eljárásokban tett kötelezettségvállalásról

21. A Gazdasági Versenyhivatal elnökének és a Gazdasági Versenyhivatal Versenytanácsa elnökének 12/2017. közleménye a fogyasztóvédelmi típusú ügyekben kiszabott bírság meghatározásának szempontjairól 
22. $1392 / B / 2007$. AB határozat

23. Kúria Kfv.III.37.697/2011/9. sz. ítélete

24. Kúria Kfv.II.37.124/2013/8. sz. ítélete

25. Kúria Kf.II.37.969/2018/10. sz. ítélete

26. Fővárosi Ítélőtábla 2.Kf.27.171/2012/4. sz. ítélete

27. GVH Vj/122/2010. sz. ügyben hozott határozata

28. GVH Vj/5/2011. sz. ügyben hozott határozata

29. GVH Vj/17/2015. sz. ügyben hozott határozata

30. GVH Vj/64/2015. sz. ügyben hozott határozata

31. GVH Vj/85/2016. sz. ügyben hozott határozata

32. GVH Vj/88/2016. sz. ügyben hozott határozata

33. GVH Vj/89/2016. sz. ügyben hozott határozata 
Dr. ZaVoDNYIK JózseF 1991 és 2001 között a biztosításfelügyeleti hatóságnál, 2001 és 2014 között a Gazdasági Versenyhivatalban dolgozott. 2001 és 2011 között a Versenytanács tagjakén több száz döntés meghozatalában vett részt. 2014 és 2016 között az Igazságügyi Minisztérium Versenyjogi, Fogyasztóvédelmi és Szellemi Tulajdonjogi Főosztályát vezette. 2016-tól ügyvéd, rendszeresen jár el versenyfelügyeleti eljárásokban, fogyasztókkal szembeni tisztességtelen kereskedelmi gyakorlatokkal kapcsolatos és más ügyekben. Közel három évtizede publikál, versenyjogi, fogyasztóvédelmi, adatvédelmi és biztosítási jogi témákban. Ezeken a területeken rendszeresen tart előadásokat, elsősorban jogi továbbképző intézetekben, egyetemeken. 